\title{
The Role of NMDAR and BDNF in Cognitive Dysfunction Induced by Different Microwave Radiation Conditions in Rats
}

\author{
Shiyao Liao ${ }^{1,2,+}$, Zonghuan Liu $1,3,+$, Weijia Zhi ${ }^{1}$, Lizhen Ma ${ }^{1}$, Hongmei Zhou ${ }^{1}$, Ruiyun Peng ${ }^{1}$, Xiangjun Hu ${ }^{1}$, \\ Yong Zou ${ }^{1, *}$ and Lifeng Wang ${ }^{1,4, *}$
}

1 Department of Pathology, Beijing Institute of Radiation Medicine, 27 Taiping Road, Beijing 100850, China; 724461737@qq.com (S.L.); 1052650892@qq.com (Z.L.); zhi.weijia@163.com (W.Z.); malizhen0906487@sina.com (L.M.); dexlic@126.com (H.Z.); ruiyunpeng18@126.com (R.P.); xjhu2003@vip.sina.com (X.H.)

2 Department of Pathology, Hunan Provincial People's Hospital, The First Affiliated Hospital of Hunan Normal University, Changsha 410002, China

3 Department of Pathology, Changzhou Maternal and Child Health Care Hospital, Changzhou 213000, China

4 Department of Basic Medicine, University of South China, Hengyang 421001, China

* Correspondence: tjuzouyong@163.com (Y.Z.); fangchang_14@163.com (L.W.)

+ These authors have contributed equally to this work.

\section{check for}

updates

Citation: Liao, S.; Liu, Z.; Zhi, W.; Ma, L.; Zhou, H.; Peng, R.; Hu, X.; Zou, Y.; Wang, L. The Role of NMDAR and BDNF in Cognitive Dysfunction Induced by Different Microwave Radiation Conditions in Rats. Radiation 2021, 1, 277-289. https://doi.org/10.3390/ radiation 1040023

Academic Editors: Gabriele Multhoff and Claus Belka

Received: 14 June 2021

Accepted: 27 September 2021

Published: 22 October 2021

Publisher's Note: MDPI stays neutral with regard to jurisdictional claims in published maps and institutional affiliations.

Copyright: (c) 2021 by the authors. Licensee MDPI, Basel, Switzerland. This article is an open access article distributed under the terms and conditions of the Creative Commons Attribution (CC BY) license (https:// creativecommons.org/licenses/by/ $4.0 /)$.
Simple Summary: Microwaves are electromagnetic waves of which frequencies range from $300 \mathrm{MHz}$ to $300 \mathrm{GHz}$, pervading diverse fields of our lives. Electromagnetic radiation can be absorbed by organisms causing a series of physiological and functional changes. The brain has been recognized as one of the most vulnerable organs to microwave radiation. However, there is no consistent conclusion about the effect of microwave radiation on human health due to the different microwave parameters, such as the frequency, modulation and radiation time. This study was focused on the role of NMDARs and BDNFs in the effects of microwave radiation on cognition.

Abstract: Background: To investigate the effects of different levels of microwave radiation on learning and memory in Wistar rats and explore the underlying mechanisms of N-methyl-D-aspartate receptor (NMDAR/NR) and Brain-derived neurotropic factor (BDNF); Methods: A total of 140 Wistar rats were exposed to microwave radiation levels of $0,10,30$ or $50 \mathrm{~mW} / \mathrm{cm}^{2}$ for $6 \mathrm{~min}$. Morris Water Maze Test, high-performance liquid chromatography, Transmission Electron Microscope and Western blotting were used; Results: The 30 and $50 \mathrm{~mW} / \mathrm{cm}^{2}$ groups exhibited longer average escape latencies and fewer platform crossings than the $0 \mathrm{~mW} / \mathrm{cm}^{2}$ group from $6 \mathrm{~h}$ to $3 \mathrm{~d}$ after microwave radiation. Alterations in the amino acid neurotransmitters of the hippocampi were shown at $6 \mathrm{~h}, 3 \mathrm{~d}$ and $7 \mathrm{~d}$ after exposure to 10,30 or $50 \mathrm{~mW} / \mathrm{cm}^{2}$ microwave radiation. The length and width of the Postsynaptic density were increased. The expression of NR1, NR2A and NR2B increased from day 1 to day 7; Postsynaptic density protein-95 and cortactin expression increased from day 3 to day 7; BDNF and Tyrosine kinase receptor B (TrkB) expression increased between $6 \mathrm{~h}$ and $1 \mathrm{~d}$ after $30 \mathrm{~mW} / \mathrm{cm}^{2}$ microwave radiation exposure, but they decreased after $50 \mathrm{~mW} / \mathrm{cm}^{2}$ exposure. Conclusions: Microwave exposure (30 or $50 \mathrm{~mW} / \mathrm{cm}^{2}$, for $6 \mathrm{~min}$ ) may cause abnormalities in neurotransmitter release and synaptic structures, resulting in impaired learning and memory; BDNF and NMDAR-related signaling molecules might contribute differently to these alterations.

Keywords: microwave; NMDAR; BDNF; hippocampus; learning and memory

\section{Introduction}

With the rapid development of microwave techniques, people are paying increasing attention to the potential dangerous effects caused by microwave radiation. Studies have shown that exposure to excessive electromagnetic radiation can cause dysfunction of 
the central nervous system [1]. The hippocampus is the structural basis of learning and memory and a highly sensitive target of microwave radiation [2,3]. To date, studies on the mechanism of learning and memory impairment caused by microwave radiation have mainly focused on synaptic plasticity, signaling pathways, energy metabolism and neurotransmitter transmission, etc. [4-8]. However, the underlying mechanisms have not yet been illuminated.

Amino acid neurotransmitters, including excitatory transmitters such as glutamic acid (Glu) and aspartic acid (Asp) and inhibitory transmitters such as gamma-aminobutyric acid (GABA) and glycine (Gly), are the most widely distributed neurotransmitters in the central nervous system. These neurotransmitters jointly regulate learning and memory by transmitting various information, and changes in their levels are closely related to neurodegenerative diseases $[9,10]$. N-methyl-D-aspartate receptor (NMDAR) is a special excitatory amino acid receptor and a voltage-dependent ligand-gated ion channel distributed in the central nervous system, mainly in the cerebral cortex and hippocampus [11,12]. NMDARs consist of three subunits: the functional subunit NR1 and the regulatory subunits NR2 (A, B, C and D) and NR3 (A and B). The physiological functions of different subunits and their contributions to synaptic plasticity are closely related to the mechanisms of learning and memory [6,13]. Postsynaptic density protein-95 (PSD-95) is a scaffold protein located in the postsynaptic density (PSD) of glutamatergic synapses that play an important role in clustering and stabilizing NMDARs on the postsynaptic membrane [14-16]. Cortactin, a microfilament actin-binding protein, is a key molecule associated with the cytoskeletal reorganization signaling pathway. It regulates actin dynamics to ensure the integration of transduced signals. When PSD95 anchors NMDAR to the PSD, it connects cytoskeletal proteins and signaling molecules through multiple related regions and contributes to dynamic changes in the cortactin cycle and synapse $[17,18]$.

Brain-derived neurotropic factor (BDNF) is an important member of the nerve growth factor family. It regulates the development and homeostasis of the central nervous system, neuronal development, differentiation, functional maintenance and synaptic plasticity by binding to the neuronal cell surface receptor, Tyrosine kinase receptor $B(\operatorname{TrkB})[19,20]$. The BDNF-TrkB signaling complex is involved in the release of glutamate through the regulation of multiple signaling pathways [21,22].

Previous studies have found that microwave radiation can cause abnormal NMDAR expression and activity [8,23], but few studies on BDNF, NMDAR and related molecules have been conducted. Therefore, changes in the expression of NMDAR (NR1, NR2A and NR2B), PSD-95, cortactin, BDNF and TrkB were assessed to elucidate the mechanism of cognitive dysfunction induced by the different microwave radiation conditions in the present study.

\section{Materials and Methods}

\subsection{Experimental Animals and Groups}

A total of 140 male Wistar rats $(200 \pm 20 \mathrm{~g})$ were purchased from the Experimental Animal Center of Beijing Institute of Radiation Medicine (Beijing, China) and kept in a specific pathogen-free (SPF) animal room. Food and water were freely available. All rats were maintained under conditions of $23 \pm 2{ }^{\circ} \mathrm{C}$ and $60 \%$ humidity with a $12 \mathrm{~h} \mathrm{light-dark}$ cycle (lights on at 7 a.m.). All the experimental animals were treated complying with rules of the Institutional Animal Care and Use Committee and the ethics review number was IACUC-DWZX- 2020 - 648.

The rats were divided into $0 \mathrm{~mW} / \mathrm{cm}^{2}$ group, $10 \mathrm{~mW} / \mathrm{cm}^{2}$ group, $30 \mathrm{~mW} / \mathrm{cm}^{2}$ group and $50 \mathrm{~mW} / \mathrm{cm}^{2}$ group by the stratified random method to eliminate the effects of differences in body weight. There were 35 rats in each group.

\subsection{Microwave Exposure}

The details of the microwave exposure system were elaborated in a previous report $[23,24]$. In short, S-band pulsed microwaves with a frequency of $2.856 \mathrm{GHz}$ were generated by 
the microwave source of a JD 2000 klystron amplifier (Vacuum Electronics Research Institute, Beijing, China). The average power densities were $10 \mathrm{~mW} / \mathrm{cm}^{2}, 30 \mathrm{~mW} / \mathrm{cm}^{2}$ or $50 \mathrm{~mW} / \mathrm{cm}^{2}$, which were measured by a waveguide antenna, GX12M30A power heads and a GX12M1CHP power meter (Guanghua Microelectronics Instruments, Hefei, China). The pattern of modulation was the pulse width of $1 \mu$ s and the repetition frequency of $250 \mathrm{~Hz}$ with different peak power densities. The radiation time was $6 \mathrm{~min}$. Before exposure, all animals were placed in the irradiation box for 5 days for adaptive training until the animals did not show resistance and automatically entered the irradiation box. During exposure, all animals were placed in the irradiation box on a radiation table. Rats in $0 \mathrm{~mW} / \mathrm{cm}^{2}$ group were processed in the same way as those in the exposure groups except with no microwave radiation, to eliminate other psychophysiological effects.

\subsection{Morris Water Maze Test (MWM)}

The MWM test was used to assess the spatial learning and memory of rodents. The test apparatus consisted of a circular stainless-steel pool (160 cm in diameter, $45 \mathrm{~cm}$ in height), a submerged platform $(12 \mathrm{~cm}$ in diameter, $15 \mathrm{~cm}$ in height, submerged $1.5 \sim 2 \mathrm{~cm}$ below the water surface), a video camera and a computer. The circular pool was divided into four quadrants (defined as the first, second, third and fourth quadrants), the depth of the water was approximately $17 \mathrm{~cm}$ and the water temperature was $21 \pm 2{ }^{\circ} \mathrm{C}$. The platform was placed in the appropriate position in the first quadrant. A curtain surrounding the water maze was used to block light, and the video camera was placed directly above the pool. The testing system software on the computer simultaneously recorded the rats' swimming trajectories in the pool and the relevant data. The rats rely on the distal cues on the walls, such as triangle and cross, to navigate from the start location of the four quadrants.

The navigation abilities of 48 rats (12 rats in each group) were tested at $0 \mathrm{~h}, 1 \mathrm{~d}$, $2 \mathrm{~d}$ and $3 \mathrm{~d}$ after microwave irradiation. Each rat was placed in the water in each of the four quadrants in turn, and when the rats entered water, they faced the maze wall. The trajectories and data of the rats were recorded. If the rat failed to find the platform within $1 \mathrm{~min}$, it was placed on the platform for $5 \mathrm{~s}$. Probe trials were carried out $14 \mathrm{~d}$ after microwave radiation. The platform was removed, the settings remained unchanged, the rats were placed in the water in the fourth quadrant, and the swimming data of crossing the platform zone were recorded for $1 \mathrm{~min}$.

\subsection{Transmission Electron Microscope (Tem)}

At $6 \mathrm{~h}, 1 \mathrm{~d}, 3 \mathrm{~d}, 7 \mathrm{~d}$ and $14 \mathrm{~d}$ after irradiation, seven rats were randomly selected from each group, injected intraperitoneally with $1 \%$ pentobarbital sodium $(30 \mathrm{mg} / \mathrm{kg}$ ) for anesthesia, and decapitated, and placed on ice. The brains were removed, and the hippocampus was dissected from each cerebral hemisphere. The left hippocampus was frozen at $-80^{\circ} \mathrm{C}$ for quantitative measurement of related proteins. The right hippocampus was used for electron microscopy and the measurement of amino acid neurotransmitter levels.

Pieces of the hippocampus $\left(1 \mathrm{~mm}^{3}\right)$ were immediately immersed in $2.5 \%$ glutaraldehyde for $2 \mathrm{~h}$, fixed in $1 \%$ osmium tetroxide for $2 \mathrm{~h}$, dehydrated with gradient ethanol and acetone solutions, embedded in Epon 812 resin, sliced into semithin sections, collected, sliced into ultrathin sections, and double stained with uranyl acetate and lead citrate. The ultrastructure of the tissue was observed by TEM and images were taken ( $\mathrm{H}-7650$, Tokyo, Japan).

\subsection{Determination of Amino Acid Neurotransmitter Levels}

The levels of Asp, Glu, Gly and GABA $\left(10^{-3} \mathrm{mg} / \mathrm{mL}\right.$ of hippocampal tissue) were measured by high-performance liquid chromatography (HPLC) $6 \mathrm{~h}, 3 \mathrm{~d}$ and $7 \mathrm{~d}$ after radiation. Before measurement, the hippocampal samples were homogenized in $10 \%$ salicylsulfonic acid and centrifuged at $15,000 \mathrm{rpm}$ for $20 \mathrm{~min}$ at $4{ }^{\circ} \mathrm{C}$. The supernatants were stored at $-20^{\circ} \mathrm{C}$ for HPLC. Every $1 \mu \mathrm{L}$ sample was added with $5 \mu \mathrm{L}$ O-phthalaldehyde for derivatization before injected into the HPLC detection system. The mobile phase (pH 6.8) 
for HPLC consisted of $100 \mathrm{mM}$ disodium hydrogen phosphate and 30\% methanol. The HPLC system was used as previously described [23].

\subsection{Western Blot Analysis of the Expression of NMDAR Subunits, BDNF and Related} Signaling Molecules

Hippocampal tissues collected $6 \mathrm{~h}, 1 \mathrm{~d}, 3 \mathrm{~d}$ and $7 \mathrm{~d}$ after microwave radiation were removed from ice, weighed, placed at the bottom of EP tubes, quickly cut and ground with RIPA lysis buffer ( $20 \mu \mathrm{L} / 0.20 \mathrm{~g}$ tissue). Total protein was extracted from the tissues. The protein concentration was determined by the Pierce ${ }^{\mathrm{TM}} \mathrm{BCA}$ Protein Assay Kit (ThermoFisher, Carlsbad, CA, USA). Then, the expression levels of NR1, NR2A, NR2B, PSD-95, cortactin, BDNF and TrkB were assessed by Western blotting according to the standard protocol. The primary antibodies were as follows: NR1 (1:1000, Abcam, Cambridge, UK), NR2A (1:1000, Abcam, Cambridge, UK), NR2B (1:1000, Abcam, Cambridge, UK), PSD-95 (1:1000, Abcam, Cambridge, UK), cortactin (1:10,000, Abcam, Cambridge, UK), BDNF (1:1000, Cambridge, UK), TrkB (1:5000, Abcam, Cambridge, UK) and GAPDH (1:10,000, Abcam, Cambridge, UK). HRP-labeled sheep anti-rabbit IgG (Beijing Zhongshan Jinqiao Biotechnology Limited Company, Beijing, China) was used as the secondary antibody. The bands were developed on autoradiographic film by using an enhanced chemiluminescence kit (Invitrogen, Carlsbad, CA, USA). The signals on the film were scanned using a highresolution scanner, and the integral optical densities of the bands on the scanned images were quantified by AlphaVIEW SA. The densities of the target bands were normalized to the density of GAPDH for the same sample.

\subsection{Statistical Analysis}

All data are expressed as the mean and standard deviation. One-way ANOVA (with post hoc multiple comparisons) was used to compare the differences in the probe trials of MWM, TEM, amino acids and Western blot. Repeated-measures ANOVA were used for the analysis of average escape latency in the MWM test. Statistical analysis was performed using SPSS18.0. ${ }^{*}$ indicates $p<0.05$, and ${ }^{* *}$ indicates $p<0.01$ of the differences between $0 \mathrm{~mW} / \mathrm{cm}^{2}$ group and three exposure groups.

\section{Results}

\subsection{Spatial Learning and Memory Deficits after Microwave Exposure}

In the MWM experiment, the navigation trials were conducted from $3 \mathrm{~d}$ after microwave radiation. The average escape latency of the $50 \mathrm{~mW} / \mathrm{cm}^{2}$ group was significantly longer than that of the $0 \mathrm{~mW} / \mathrm{cm}^{2}$ group at $6 \mathrm{~h}$ after microwave radiation $(p<0.05)$; there was no significant difference in the average escape latency between the three radiation groups and the $0 \mathrm{~mW} / \mathrm{cm}^{2}$ group $1 \mathrm{~d}$ after microwave radiation. The average escape latency of the $30 \mathrm{~mW} / \mathrm{cm}^{2}$ and $50 \mathrm{~mW} / \mathrm{cm}^{2}$ group was significantly longer on day 2 $(p<0.05)$; and that of the $10 \mathrm{~mW} / \mathrm{cm}^{2}$ and $50 \mathrm{~mW} / \mathrm{cm}^{2}$ group was significantly longer than the $0 \mathrm{~mW} / \mathrm{cm}^{2}$ group $3 \mathrm{~d}$ after microwave radiation $(p<0.05)$ (Figure $\left.1 \mathrm{~A}\right)$.

The probe trials were conducted $14 \mathrm{~d}$ after microwave radiation, and it was found that the number of platform crossings was significantly reduced in the $50 \mathrm{~mW} / \mathrm{cm}^{2}$ group $(p<0.05)$. This result indicated that $50 \mathrm{~mW} / \mathrm{cm}^{2}$ microwave radiation might impair spatial learning and memory in rats (Figure 1B). 


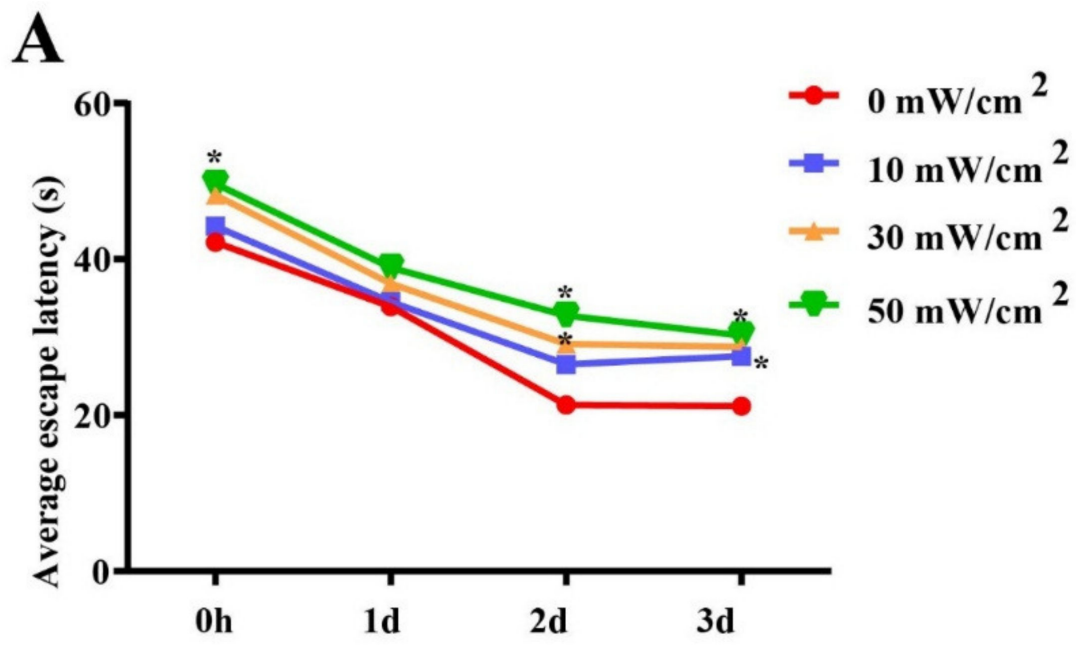

Time after microwave exposure

B

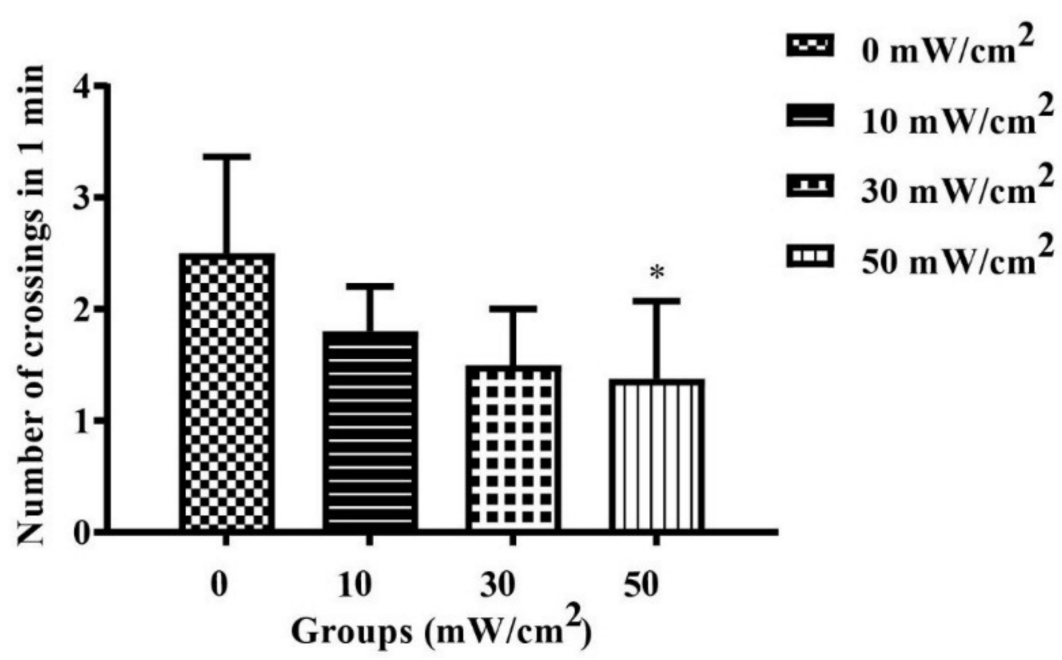

Figure 1. Effect of microwave radiation on spatial learning and memory in the MWM. (A) The average escape latency in the navigation test $0 \mathrm{~h}-3 \mathrm{~d}$ after 10,30 and $50 \mathrm{~mW} / \mathrm{cm}^{2}$ microwave radiation. (B) The number of crossings in the probe trials $14 \mathrm{~d}$ after 10,30 and $50 \mathrm{~mW} / \mathrm{cm}^{2}$ microwave radiation. Compared with $0 \mathrm{~mW} / \mathrm{cm}^{2}$ group, ${ }^{*} p<0.05$.

\subsection{Ultrastructural Changes in the Rat Hippocampus after Microwave Radiation}

To observe the effect of microwave radiation on synaptic ultrastructure, a transmission electron microscope was used in this study. The ultrastructure of the hippocampus in $0 \mathrm{~mW} / \mathrm{cm}^{2}$ group was normal (Figure 2(A1)). However, the thickness and length of the PSD were increased (Figure 2(A2-4)-C) in the hippocampi of rats exposed to microwaves, especially those in the 30 and $50 \mathrm{~mW} / \mathrm{cm}^{2}$ groups. 

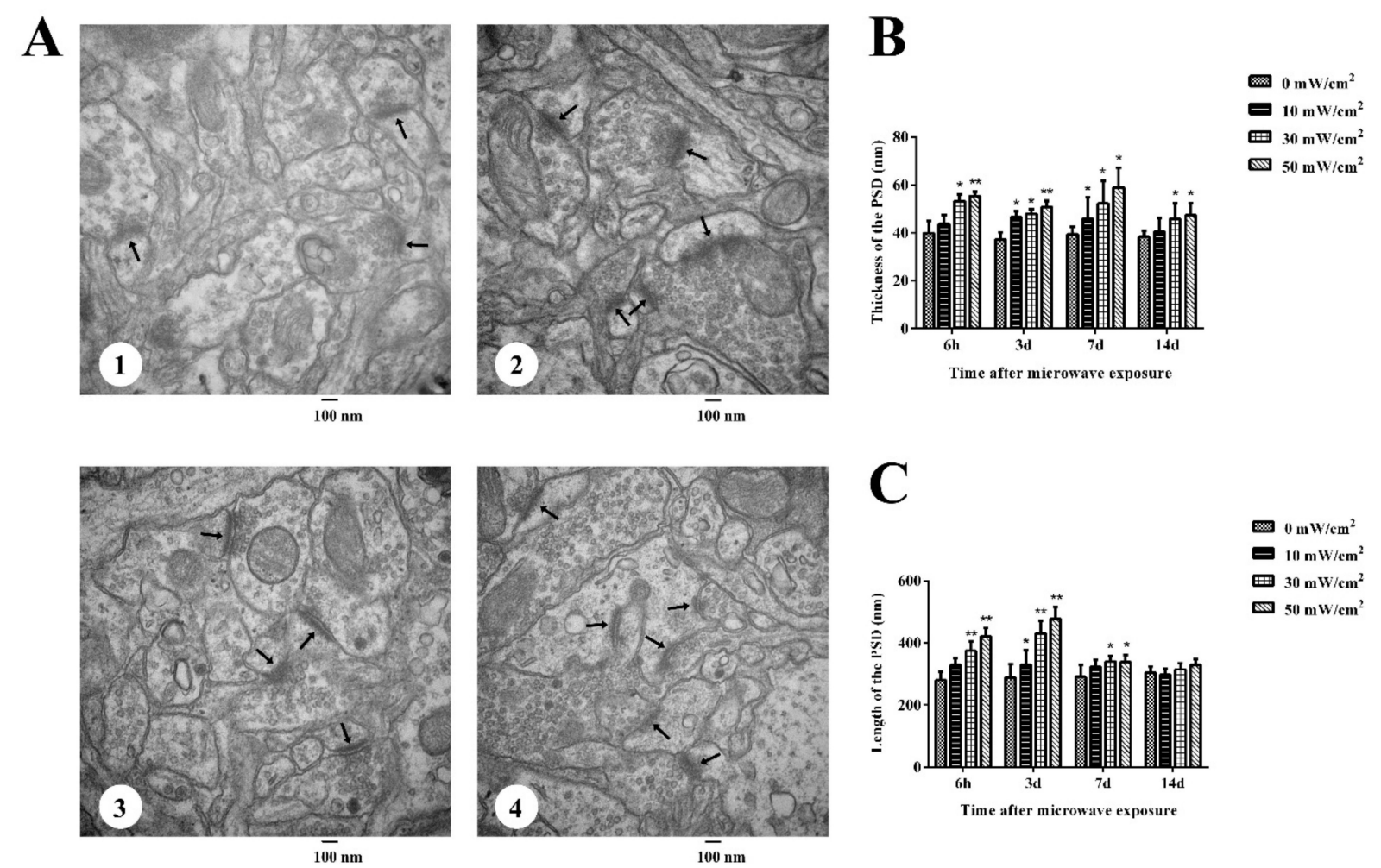

Figure 2. Hippocampal synaptic ultrastructure after microwave radiation. (A) $1-4$ : Images of $0 \mathrm{~mW} / \mathrm{cm}^{2}, 10 \mathrm{~mW} / \mathrm{cm}^{2}$, $30 \mathrm{~mW} / \mathrm{cm}^{2}$ and $50 \mathrm{~mW} / \mathrm{cm}^{2}$ groups at $3 \mathrm{~d}$ after microwave radiation. Scale bars $=100 \mathrm{~nm}$. (B,C) Quantitative analysis of $\operatorname{PSD}(\rightarrow)$ thickness and length. Compared with $0 \mathrm{~mW} / \mathrm{cm}^{2}$ group, ${ }^{*} p<0.05,{ }^{* *} p<0.01$.

\subsection{Levels of Amino Acid Neurotransmitters in the Hippocampus}

Based on the results of the MWM test and hippocampal ultrastructure analysis, the levels of Asp, Glu, Gly and GABA in the hippocampus were measured at $6 \mathrm{~h}, 3 \mathrm{~d}$ and $7 \mathrm{~d}$ after microwave radiation. For Asp, the effects of $10 \mathrm{~mW} / \mathrm{cm}^{2}$ and $30 \mathrm{~mW} / \mathrm{cm}^{2}$ microwave radiation on its contents in the hippocampus were roughly the same (Figure $3 \mathrm{~A})$. Firstly, the levels of Asp decreased at $6 \mathrm{~h}$ after microwave radiation, then they were upregulated $3 \mathrm{~d}$ after microwave radiation, which was equivalent to that of the $0 \mathrm{~mW} / \mathrm{cm}^{2}$ group, and finally returned to a relatively low levels $7 \mathrm{~d}$ after microwave radiation. The influence of $50 \mathrm{~mW} / \mathrm{cm}^{2}$ microwave radiation on the levels of ASP was completely opposite to that of the $10 \mathrm{~mW} / \mathrm{cm}^{2}$ and $30 \mathrm{~mW} / \mathrm{cm}^{2}$ groups. The expression of ASP did not change at $6 \mathrm{~h}$, but decreased significantly on day 3 and 7 after $50 \mathrm{~mW} / \mathrm{cm}^{2}$ microwave radiation compared with the $0 \mathrm{~mW} / \mathrm{cm}^{2}$ group $(p<0.05)$.

For Glu, the effects of $10 \mathrm{~mW} / \mathrm{cm}^{2}$ and $50 \mathrm{~mW} / \mathrm{cm}^{2}$ microwave radiation on its contents in the hippocampus were basically similar (Figure 3B). Results showed that the levels of Glu were significantly upregulated at $6 \mathrm{~h}$, and tended to be stable on day 3 and 7 after $10 \mathrm{~mW} / \mathrm{cm}^{2}$ and $50 \mathrm{~mW} / \mathrm{cm}^{2}$ radiation, which were equivalent to the level of the $0 \mathrm{~mW} / \mathrm{cm}^{2}$ group $(p>0.05)$. The effect of $30 \mathrm{~mW} / \mathrm{cm}^{2}$ microwave radiation on Glu contents was completely the opposite to that of the $10 \mathrm{~mW} / \mathrm{cm}^{2}$ and $50 \mathrm{~mW} / \mathrm{cm}^{2}$ groups. At $6 \mathrm{~h}$ after $30 \mathrm{~mW} / \mathrm{cm}^{2}$ microwave radiation, the initial level was basically the same as that of the $0 \mathrm{~mW} / \mathrm{cm}^{2}$ group, but then the levels of Glu were significantly and extremely significantly upregulated on day $3(p<0.05)$ and $7 \mathrm{~d}(p<0.01)$ after microwave radiation, respectively.

The effects of $10 \mathrm{~mW} / \mathrm{cm}^{2}, 30 \mathrm{~mW} / \mathrm{cm}^{2}$ and $50 \mathrm{~mW} / \mathrm{cm}^{2}$ microwave radiation on Gly levels were almost alike (Figure 3C), showing that the contents of Glu decreased at $6 \mathrm{~h}$ and $3 \mathrm{~d}$ after radiation, and recovered to the normal level $7 \mathrm{~d}$ after microwave radiation ( $p>0.05$ in the three groups). 
For GABA (Figure 3D), the contents decreased significantly at $6 \mathrm{~h}(p<0.01)$, then increased on day $3(p<0.01)$, and finally returned to the normal level on day 7 after $10 \mathrm{~mW} / \mathrm{cm}^{2}$ and $30 \mathrm{~mW} / \mathrm{cm}^{2}$ microwave radiation. However, the effect of $50 \mathrm{~mW} / \mathrm{cm}^{2}$ on GABA contents was different. There was no significant difference between the $0 \mathrm{~mW} / \mathrm{cm}^{2}$ and $50 \mathrm{~mW} / \mathrm{cm}^{2}$ groups at $6 \mathrm{~h}$, then it was significantly upregulated on day $3(p<0.05)$ and returned to normal levels on day $7(p<0.01)$ after $50 \mathrm{~mW} / \mathrm{cm}^{2}$ microwave radiation.

A
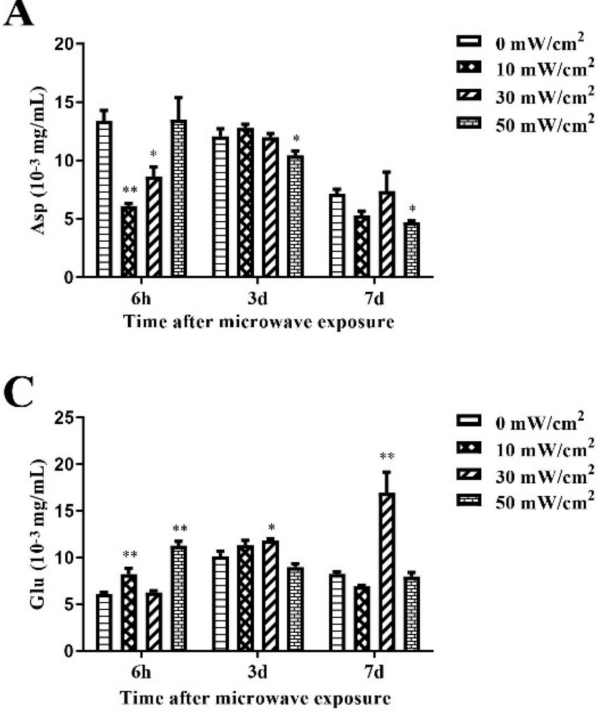

B

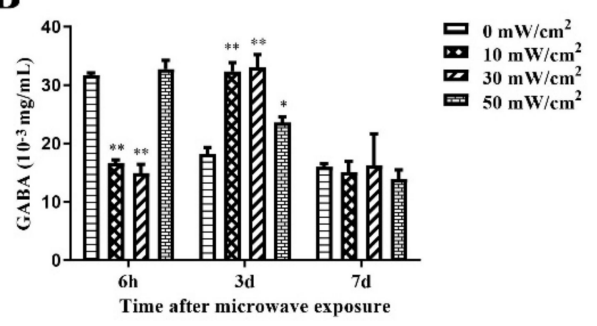

D

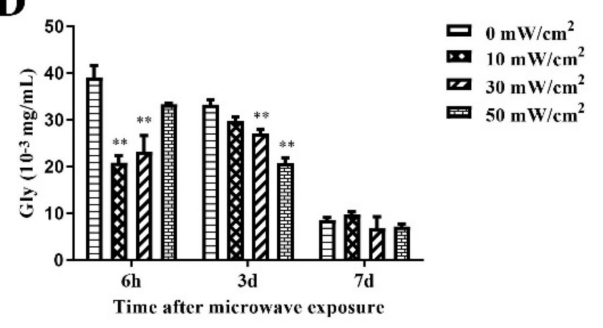

Figure 3. The levels of amino acid neurotransmitters in the rat hippocampus after microwave radiation. (A-D) Compared with $0 \mathrm{~mW} / \mathrm{cm}^{2}$ group, $* p<0.05, * * p<0.01$.

\subsection{Effects of Microwave Exposure on the Levels of NMDAR, BDNF and Related Molecules}

To investigate the mechanism underlying the effect of microwave radiation on cognition, changes in the levels of NMDAR, BDNF and related molecules at different times after exposure to different microwave radiation conditions were investigated. First, we studied the changes in NMDAR levels under different conditions, as shown in Figure 4A-C. There was no significant change in the protein expression of NR1, NR2A and NR2B between the $10 \mathrm{~mW} / \mathrm{cm}^{2}$ group and $0 \mathrm{~mW} / \mathrm{cm}^{2}$ group at $6 \mathrm{~h}, 1 \mathrm{~d}, 3 \mathrm{~d}$ and $7 \mathrm{~d}$ after microwave radiation; the expression of NR1, NR2A and NR2B in the $30 \mathrm{~mW} / \mathrm{cm}^{2}$ group was increased at $1 \mathrm{~d}$, $3 \mathrm{~d}, 7 \mathrm{~d}$ after microwave radiation, and the expression of NR1, NR2A and NR2B in the $50 \mathrm{~mW} / \mathrm{cm}^{2}$ group was decreased at $6 \mathrm{~h}, 1 \mathrm{~d}, 3 \mathrm{~d}$ and $7 \mathrm{~d}$ after microwave radiation.

To evaluate the effect of BDNF on NMDAR, we assessed the expression of BDNF and TrkB at $6 \mathrm{~h}, 1 \mathrm{~d}$ and $3 \mathrm{~d}$ after microwave radiation. As shown in Figure $4 \mathrm{D}, \mathrm{E}$, the expression of BDNF was increased in the $30 \mathrm{~mW} / \mathrm{cm}^{2}$ group and decreased in the $50 \mathrm{~mW} / \mathrm{cm}^{2}$ group at $6 \mathrm{~h}$ after microwave radiation. The expression of BDNF and TrkB was increased in the $30 \mathrm{~mW} / \mathrm{cm}^{2}$ group and decreased in the $50 \mathrm{~mW} / \mathrm{cm}^{2}$ group at $1 \mathrm{~d}$ after microwave radiation.

The expression of the downstream molecules PSD95 and cortactin was measured $1 \mathrm{~d}$, $3 \mathrm{~d}$ and $7 \mathrm{~d}$ after microwave radiation. As shown in Figure $4 \mathrm{~F}, \mathrm{G}$, the expression levels of PSD95 and Cortactin were increased in the $30 \mathrm{~mW} / \mathrm{cm}^{2}$ group $3 \mathrm{~d}$ after microwave radiation and decreased in the $50 \mathrm{~mW} / \mathrm{cm}^{2}$ group. PSD95 showed the same trend $7 \mathrm{~d}$ after microwave radiation. 

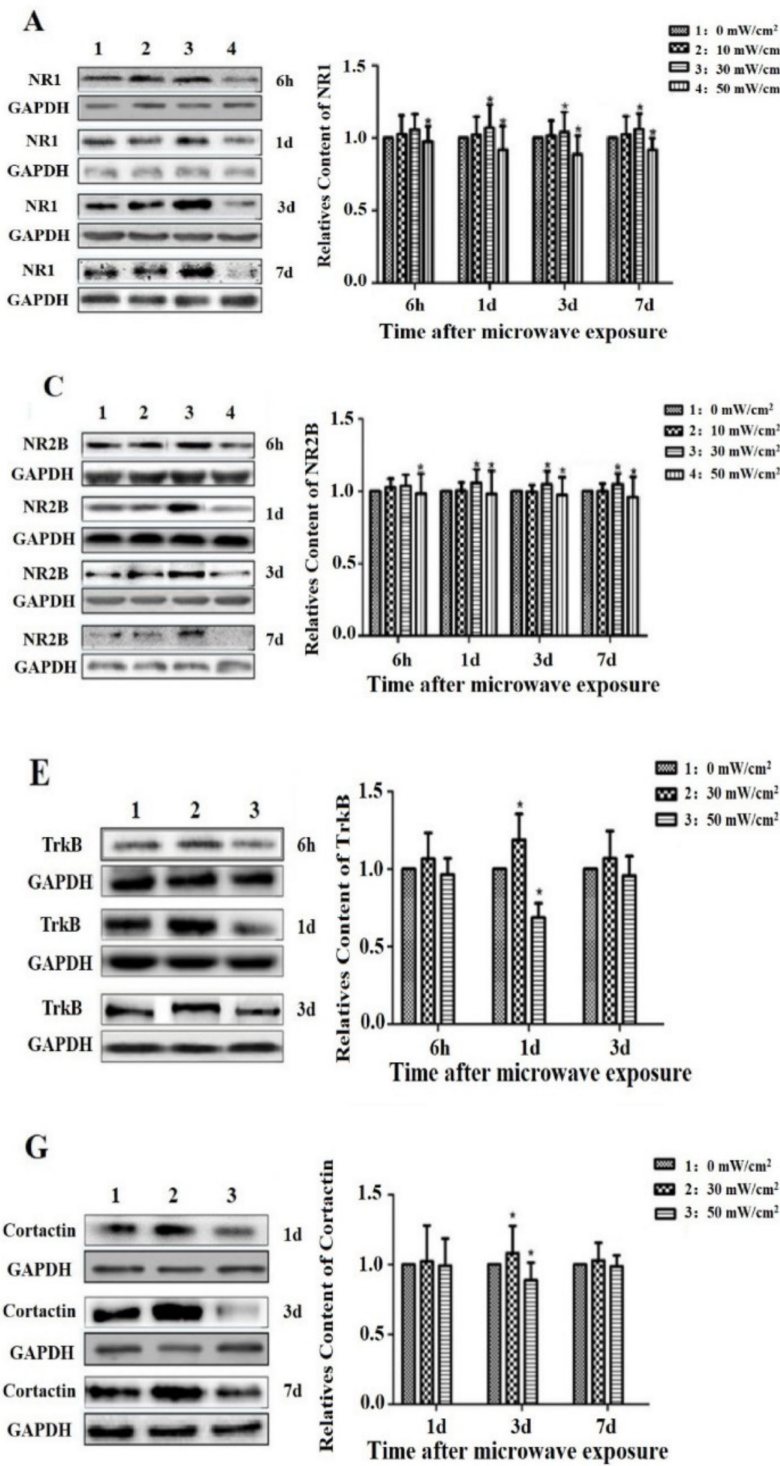

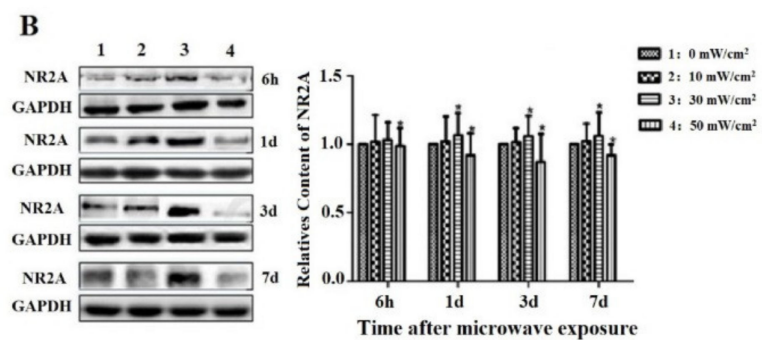

D
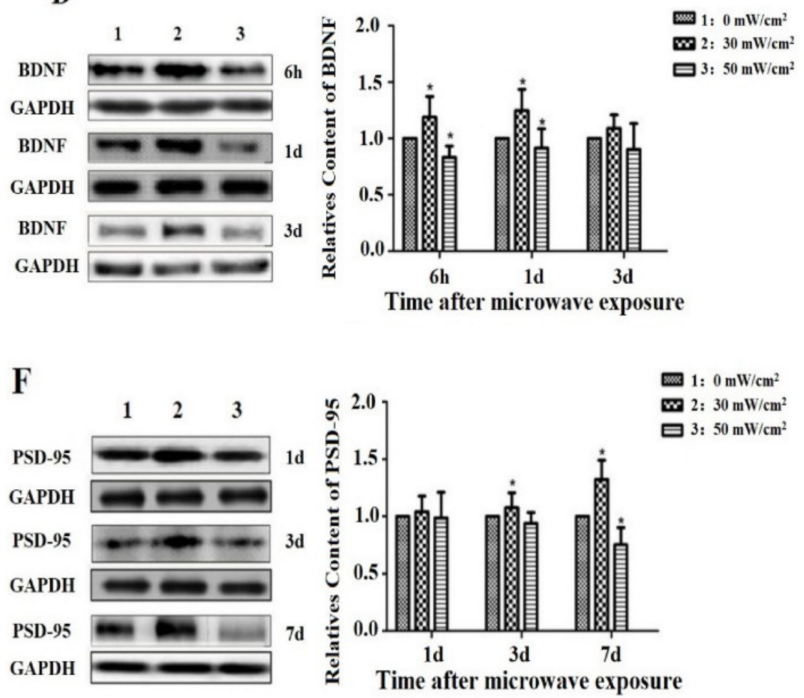

Figure 4. The protein expression of NR1, NR2A, NR2B, BDNF, TrkB, PSD95 and Cortactin after microwave radiation. (A) The protein expression level of NR1. (B) The protein expression level of NR2A. (C) The protein expression level of NR2B. (D) The protein expression level of BDNF. (E) The protein expression level of TrkB. (F) The protein expression level of PSD95. (G) The protein expression level of Cortactin. The data are expressed as the means and standard deviations. 1, 2, 3, 4: Compared with $0 \mathrm{~mW} / \mathrm{cm}^{2}$ group, ${ }^{*} p<0.05$.

\section{Discussion}

Many studies have shown that learning and memory abilities, which are advanced functions of the brain, especially spatial memory ability, are dependent on the integrity of the hippocampus [25-27]. Cognitive impairment is one of the most important effects of microwave-induced damage [28,29]. The MWM experiment is a classic experiment used to evaluate the spatial learning and memory abilities of rodents [30-34]. Zhao L [35] found that learning and memory were impaired in Wistar rats exposed to microwaves with an average power density of $10 \mathrm{~mW} / \mathrm{cm}^{2}$ and an average calculated specific absorption rate (SAR) of $4.2 \mathrm{~W} / \mathrm{kg}$. Deshmukh PS [36] demonstrated that exposure to 900,1800 or $2450 \mathrm{MHz}$ microwave radiation with a SAR of $5.953 \times 10^{-4} \mathrm{~W} / \mathrm{kg}, 5.835 \times 10^{-4} \mathrm{~W} / \mathrm{kg}$ or $6.672 \times 10^{-4} \mathrm{~W} / \mathrm{kg}$, respectively, for $90 \mathrm{~d}(2 \mathrm{~h} / \mathrm{d}, 5 \mathrm{~d} /$ week $)$ could lead to a decline in cognitive function. In our study, there was no significant change in the average escape latency of the $10 \mathrm{~mW} / \mathrm{cm}^{2}$ group, but the $30 \mathrm{~mW} / \mathrm{cm}^{2}$ and $50 \mathrm{~mW} / \mathrm{cm}^{2}$ groups exhib- 
ited significantly longer average escape latencies and fewer platform crossings than the $0 \mathrm{~mW} / \mathrm{cm}^{2}$ group $14 \mathrm{~d}$ after $50 \mathrm{~mW} / \mathrm{cm}^{2}$ microwave radiation. The results may indicate that $30 \mathrm{~mW} / \mathrm{cm}^{2}$ and $50 \mathrm{~mW} / \mathrm{cm}^{2}$ microwave radiation can lead to cognitive dysfunction and that the greater the average power density, the more severe the cognitive dysfunction.

Amino acid neurotransmitters are widely distributed in the central nervous system [37]. According to their functions, they can be divided into excitatory and inhibitory amino acids. Glu is the most important excitatory amino acid, and GABA is the most important inhibitory amino acid, and together they regulate learning and memory functions in the brain [38,39]. Changes in amino acid neurotransmitter levels are closely related to neurodegeneration, brain injury and learning and memory [40-42]. Xiong L found that following exposure of PC12 cells to $30-\mathrm{mW} / \mathrm{cm}^{2}$ microwave radiation for $5 \mathrm{~min}$, the ratio of released Glu and GABA increased markedly, suggesting that Glu, as a basic excitatory neurotransmitter, might play a key role in microwave-associated synaptic plasticity impairment [24]. In another study, Wistar rats were exposed to a 2.856-GHz pulsed microwave radiation at a power density of $50 \mathrm{~mW} / \mathrm{cm}^{2}$ for $6 \mathrm{~min}$. The results showed than Glu levels were significantly decreased at 3,9 and 12 months after microwave exposure. The ratio of Glu and GABA was significantly decreased at 6 months. This indicated that microwave exposure can cause changes in the excitability, which may be related to the accumulation of metabolic products or the imbalance of the internal environment [43]. Our previous research revealed that following microwave exposure for $5 \mathrm{~min}$ at an average power density of $10 \mathrm{~mW} / \mathrm{cm}^{2}$, there was a significant decrease in Glu levels at $6 \mathrm{~h}, 1 \mathrm{~d}$ and $7 \mathrm{~d}$ indicating that amino acid metabolism was disturbed, which may play an important role in the neuronal damage induced by microwave exposure [44]. In this study, there was an increase in Glu levels and fluctuations in GABA levels in the $10 \mathrm{~mW} / \mathrm{cm}^{2}$ and $30 \mathrm{~mW} / \mathrm{cm}^{2}$ groups and increases in Glu and GABA levels in the $50 \mathrm{~mW} / \mathrm{cm}^{2}$ group. The results suggest that microwave radiation can cause the disturbance of amino acid neurotransmitters, resulting in excitability changes after exposure to $10 \mathrm{~mW} / \mathrm{cm}^{2}$ or $30 \mathrm{~mW} / \mathrm{cm}^{2}$ microwave radiation and inhibitory changes after exposure to $50 \mathrm{~mW} / \mathrm{cm}^{2}$ microwave radiation. These results are not consistent with those of previous studies, but the damage mechanisms may have been different due to differences in the radiation dosage and exposure time.

The hippocampus is an important component of the limbic system in humans and other vertebrates. Two of its important functions are learning and memory, which are highly sensitive to microwave exposure $[45,46]$. The normal morphological structure of the hippocampus is the structural basis for the maintenance of normal behavior and cognition. It has been reported that microwave radiation can induce synaptic plasticity impairment, which is characterized by a decrease in the number of synaptic vesicles, mitochondrial swelling, postsynaptic membrane perforation, abnormal postsynaptic membrane length and density distribution and rough endoplasmic reticulum expansion [3,47-49]. In our experiment, ultrastructural analysis of the hippocampus showed increases in the PSD and the length of the active area, which became more pronounced as the average power density increased. These changes may have been due to the dysfunction of amino acid neurotransmitter metabolism after microwave radiation and may have caused compensatory changes in synaptic structure.

It is well known that synaptic plasticity is the neurobiological basis of learning and memory [50]. NMDARs present on the presynaptic and postsynaptic membrane bound with glutamate released from presynaptic terminals to regulate synaptic plasticity $[6,13]$. NMDARs are composed of NR1 and NR2 or NR3 subunits, among which NR2A and NR2B play key roles in activity-dependent synaptic plasticity [51]. Wang $\mathrm{H}$ [23] studied the effects of $2.856 \mathrm{GHz}$ radiation with an average power density of $2.5,5$ or $10 \mathrm{~mW} / \mathrm{cm}^{2}$ for $6 \mathrm{~min} /$ day ( $5 \mathrm{~d} /$ week, up to 6 weeks) on NMDARs expressions and phosphorylation. It was found that NR2A, NR2B and p-NR2B expression were decreased in the $10 \mathrm{~mW} / \mathrm{cm}^{2}$ group compared with the $0 \mathrm{~mW} / \mathrm{cm}^{2}$ group. In our study, the expression of NR1, NR2A and NR2B in the $10 \mathrm{~mW} / \mathrm{cm}^{2}$ group was not statistically significant from that in the $0 \mathrm{~mW} / \mathrm{cm}^{2}$ group due to the radiation exposure time; the expression levels of the NMDAR 
subunits NR1, 2A and 2B were increased in the $30 \mathrm{~mW} / \mathrm{cm}^{2}$ group but decreased in the $50 \mathrm{~mW} / \mathrm{cm}^{2}$ group 1 and $3 \mathrm{~d}$ after microwave radiation. Therefore, we chose 30 and $50 \mathrm{~mW} / \mathrm{cm}^{2}$ radiation for subsequent studies.

PSD-95 affects the redistribution of the postsynaptic structural protein cortactin, regulates synaptic plasticity and promotes the recovery of learning and memory abilities. Cortactin is an F-actin-binding protein that is related to the stabilization and differentiation of actin filaments and participates in neuronal activity-dependent synaptic plasticity $[52,53]$. The Shank-Cortactin interaction provides a potential connection between the postsynaptic NMDAR-PSD-95 complex and the actin cytoskeleton of dendritic spines [18]. This study revealed that microwave radiation caused an increase in the expression of PSD-95 and Cortactin in the $30 \mathrm{~mW} / \mathrm{cm}^{2}$ group but a decrease in the expression of these proteins in the $50 \mathrm{~mW} / \mathrm{cm}^{2}$ group, which was in accordance with the change in NMDAR. BDNF is synthesized in the brain and is distributed in the central nervous system, which plays an important role in the survival, differentiation and growth of neurons [19,22]. Studies have found that BDNF activates NMDAR by acting on the TrkB receptor, causing cytotoxicity $[15,21,54]$. This study revealed that microwave radiation caused an increase in the expression of BDNF and its receptor TrkB in the $30 \mathrm{~mW} / \mathrm{cm}^{2}$ group and a decrease in the expression of these proteins in the $50 \mathrm{~mW} / \mathrm{cm}^{2}$ group. These results show that after $30 \mathrm{~mW} / \mathrm{cm}^{2}$ microwave exposure, BDNF expression is upregulated, and BDNF specifically binds to the TrkB receptor on the target cell membrane, activating its signal transduction pathway and possibly upregulating the expression of the NR1, NR2A and NR2B subunits and causing PSD-95 and Cortactin to anchor NMDARs to the PSD, allowing the activation of NMDAR. However, the levels of NMDAR and related proteins were decreased after $50 \mathrm{~mW} / \mathrm{cm}^{2}$ microwave radiation, and BDNF may have downregulated the expression of NMDAR subunits, leading to downregulated PSD activity and cognitive dysfunction.

\section{Conclusions}

In summary, microwave radiation $\left(2.856 \mathrm{GHz}\right.$, average power density of 30 or $50 \mathrm{~mW} / \mathrm{cm}^{2}$ for $6 \mathrm{~min}$ ) may cause disturbances in amino acid neurotransmitters, abnormalities in synaptic structure and cognitive dysfunction, and BDNF and NMDAR play an important role in these alterations via their signaling pathways. However, further study of this mechanism is required.

Author Contributions: Conceptualization, L.W., X.H. and R.P.; methodology, L.W.; software, Y.Z.; validation, S.L. and Z.L.; formal analysis, S.L.; investigation, H.Z.; resources, L.W.; data curation, S.L. and Z.L.; writing—original draft preparation, W.Z.; writing—review and editing, L.W., X.H. and R.P.; visualization, L.M.; supervision, W.Z.; project administration, L.W.; funding acquisition, L.W. All authors have read and agreed to the published version of the manuscript.

Funding: This work was supported by the National Natural Science Foundation of China (61571455), Key Program of Logistics Research (BWS16J011) and Innovation Foundation of Beijing Institute of Radiation Medicine (2015CXJJ004). The funders had no role in the study design, data collection and analysis, decision to publish, or preparation of the manuscript.

Institutional Review Board Statement: All the experimental animals were treated complying with rules of the Institutional Animal Care and Use Committee and the ethics review number was IACUCDWZX-2020-648.

Informed Consent Statement: Not applicable.

Data Availability Statement: The data presented in this study are available on request from the corresponding author.

Conflicts of Interest: The authors declare no conflict of interest. 


\section{References}

1. Foerster, M.; Thielens, A.; Joseph, W.; Eeftens, M.; Röösli, M. A Prospective Cohort Study of Adolescents' Memory Performance and Individual Brain Dose of Microwave Radiation from Wireless Communication. Environ. Health Perspect. 2018, $126,077007$. [CrossRef]

2. Wang, F.; Wan, P.; Wang, W.; Xiao, B.; Jin, H.; Jin, Q. Dopamine in the hippocampal dentate gyrus modulates spatial learning via D1-like receptors. Brain Res. Bull. 2019, 144, 101-107. [CrossRef] [PubMed]

3. Zhi, W.-J.; Peng, R.-Y.; Li, H.-J.; Zou, Y.; Yao, B.-W.; Wang, C.-Z.; Liu, Z.-H.; Gao, X.-H.; Xu, X.-P.; Dong, J.; et al. Microwave radiation leading to shrinkage of dendritic spines in hippocampal neurons mediated by SNK-SPAR pathway. Brain Res. 2018, 1679, 134-143. [CrossRef]

4. Suárez-Pozos, E.; Thomason, E.J.; Fuss, B. Glutamate Transporters: Expression and Function in Oligodendrocytes. Neurochem. Res. 2020, 45, 551-560. [CrossRef] [PubMed]

5. Stachowicz, K. Behavioral consequences of co-administration of MTEP and the COX-2 inhibitor NS398 in mice. Part 1. Behav. Brain Res. 2019, 370, 111961. [CrossRef]

6. Zhou, L.; Duan, J. The C-terminus of NMDAR GluN1-1a Subunit Translocates to Nucleus and Regulates Synaptic Function. Front. Cell. Neurosci. 2018, 12, 334. [CrossRef]

7. Wang, H.; Zhang, J.; Hu, S.H.; Tan, S.Z.; Zhang, B.; Zhou, H.M.; Peng, R.Y. Real-time Microwave Exposure Induces Calcium Efflux in Primary Hippocampal Neurons and Primary Cardiomyocytes. Biomed. Environ. Sci. BES 2018, 31, 561-571. [CrossRef]

8. Wang, H.; Tan, S.; Zhao, L.; Dong, J.; Yao, B.; Xu, X.; Zhang, B.; Zhang, J.; Zhou, H.; Peng, R. Protective Role of NMDAR for Microwave-Induced Synaptic Plasticity Injuries in Primary Hippocampal Neurons. Cell. Physiol. Biochem. Int. J. Exp. Cell. Physiol. Biochem. Pharmacol. 2018, 51, 97-112. [CrossRef] [PubMed]

9. Ngo, D.-H.; Vo, T.S. An Updated Review on Pharmaceutical Properties of Gamma-Aminobutyric Acid. Molecules 2019, 24, 2678. [CrossRef]

10. Magi, S.; Piccirillo, S.; Amoroso, S. The dual face of glutamate: From a neurotoxin to a potential survival factor-Metabolic implications in health and disease. Cell. Mol. Life Sci. CMLS 2019, 76, 1473-1488. [CrossRef]

11. Lodge, D.; Watkins, J.C.; Bortolotto, Z.A.; Jane, D.E.; Volianskis, A. The 1980s: D-AP5, LTP and a Decade of NMDA Receptor Discoveries. Neurochem. Res. 2019, 44, 516-530. [CrossRef]

12. Sadat-Shirazi, M.-S.; Ahmadian-Moghadam, H.; Khalifeh, S.; Zadeh-Tehrani, S.N.; Farahmandfar, M.; Zarrindast, M.-R. The role of calcium-calmodulin-dependent protein kinase II in modulation of spatial memory in morphine sensitized rats. Behav. Brain Res. 2019, 359, 298-303. [CrossRef]

13. Kumar, A.; Foster, T.C. Alteration in NMDA Receptor Mediated Glutamatergic Neurotransmission in the Hippocampus During Senescence. Neurochem. Res. 2019, 44, 38-48. [CrossRef] [PubMed]

14. Coley, A.A.; Gao, W.-J. PSD95: A synaptic protein implicated in schizophrenia or autism? Prog. Neuro-Psychopharmacol. Biol. Psychiatry 2018, 82, 187-194. [CrossRef] [PubMed]

15. Lu, Y.; Sun, G.; Yang, F.; Guan, Z.; Zhang, Z.; Zhao, J.; Liu, Y.; Chu, L.; Pei, L. Baicalin regulates depression behavior in mice exposed to chronic mild stress via the Rac/LIMK/cofilin pathway. Biomed. Pharmacother. 2019, 116, 109054. [CrossRef] [PubMed]

16. Mardones, M.D.; Jorquera, P.V.; Herrera-Soto, A.; Ampuero, E.; Bustos, F.J.; van Zundert, B.; Varela-Nallar, L. PSD95 regulates morphological development of adult-born granule neurons in the mouse hippocampus. J. Chem. Neuroanat. 2019, 98, 117-123. [CrossRef]

17. Schnoor, M.; Stradal, T.E.; Rottner, K. Cortactin: Cell Functions of A Multifaceted Actin-Binding Protein. Trends Cell Biol. 2018, 28, 79-98. [CrossRef]

18. Scherer, A.N.; Anand, N.S.; Koleske, A.J. Cortactin stabilization of actin requires actin-binding repeats and linker, is disrupted by specific substitutions, and is independent of nucleotide state. J. Biol. Chem. 2018, 293, 13022-13032. [CrossRef]

19. Liu, Y.-X.; Yan, D. Effects of dexmedetomidine on the growth and development of rat hippocampal neurons and its mechanism. Zhongguo Yingyong Shenglixue Zazhi Chin. J. Appl. Physiol. 2019, 35, 69-73. [CrossRef]

20. Wang, Z.-H.; Xiang, J.; Liu, X.; Yu, S.P.; Manfredsson, F.P.; Sandoval, I.M.; Wu, S.; Wang, J.-Z.; Ye, K. Deficiency in BDNF/TrkB Neurotrophic Activity Stimulates $\delta$-Secretase by Upregulating C/EBP $\beta$ in Alzheimer's Disease. Cell Rep. 2019, 28, 655-669. [CrossRef]

21. Lin, T.W.; Harward, S.C.; Huang, Y.Z.; McNamara, J.O. Targeting BDNF/TrkB pathways for preventing or suppressing epilepsy. Neuropharmacology 2020, 167, 107734. [CrossRef]

22. Sharma, P.; Kumar, A.; Singh, D. Dietary Flavonoids Interaction with CREB-BDNF Pathway: An Unconventional Approach for Comprehensive Management of Epilepsy. Curr. Neuropharmacol. 2019, 17, 1158-1175. [CrossRef]

23. Wang, H.; Tan, S.; Xu, X.; Zhao, L.; Zhang, J.; Yao, B.; Gao, Y.; Zhou, H.; Peng, R. Long term impairment of cognitive functions and alterations of NMDAR subunits after continuous microwave exposure. Physiol. Behav. 2017, 181, 1-9. [CrossRef] [PubMed]

24. Xiong, L.; Sun, C.F.; Zhang, J.; Gao, Y.B.; Wang, L.F.; Zuo, H.Y.; Wang, S.M.; Zhou, H.M.; Xu, X.P.; Dong, J.; et al. Microwave exposure impairs synaptic plasticity in the rat hippocampus and PC12 cells through over-activation of the NMDA receptor signaling pathway. Biomed. Environ. Sci. BES 2015, 28, 13-24. [CrossRef] [PubMed]

25. Bellmund, J.L.; Deuker, L.; Doeller, C.F. Mapping sequence structure in the human lateral entorhinal cortex. eLife 2019, 8. [CrossRef] 
26. Ramanathan, K.R.; Maren, S. Nucleus reuniens mediates the extinction of contextual fear conditioning. Behav. Brain Res. 2019, 374, 112114. [CrossRef]

27. Trinchero, M.F.; Herrero, M.; Monzón-Salinas, M.C.; Schinder, A.F. Experience-Dependent Structural Plasticity of Adult-Born Neurons in the Aging Hippocampus. Front. Neurosci. 2019, 13, 739. [CrossRef]

28. Hassanshahi, A.; Shafeie, S.A.; Fatemi, I.; Hassanshahi, E.; Allahtavakoli, M.; Shabani, M.; Roohbakhsh, A.; Shamsizadeh, A. The effect of Wi-Fi electromagnetic waves in unimodal and multimodal object recognition tasks in male rats. Neurol. Sci. Off. J. Ital. Neurol. Soc. Ital. Soc. Clin. Neurophysiol. 2017, 38, 1069-1076. [CrossRef] [PubMed]

29. Sharma, A.; Kesari, K.K.; Saxena, V.K.; Sisodia, R. Ten gigahertz microwave radiation impairs spatial memory, enzymes activity, and histopathology of developing mice brain. Mol. Cell. Biochem. 2017, 435, 1-13. [CrossRef]

30. Barry, D.N.; Commins, S. A novel control condition for spatial learning in the Morris water maze. J. Neurosci. Methods 2019, 318, 1-5. [CrossRef]

31. Levit, A.; Regis, A.M.; Gibson, A.; Hough, O.H.; Maheshwari, S.; Agca, Y.; Agca, C.; Hachinski, V.; Allman, B.L.; Whitehead, S.N Impaired behavioural flexibility related to white matter microgliosis in the TgAPP21 rat model of Alzheimer disease. Brain Behav. Immun. 2019, 80, 25-34. [CrossRef] [PubMed]

32. Reynolds, N.C.; Zhong, J.Y.; Clendinen, C.A.; Moffat, S.D.; Magnusson, K.R. Age-related differences in brain activations during spatial memory formation in a well-learned virtual Morris water maze (vMWM) task. NeuroImage 2019, 202, 116069. [CrossRef] [PubMed]

33. Vouros, A.; Gehring, T.V.; Szydlowska, K.; Janusz, A.; Tu, Z.; Croucher, M.; Lukasiuk, K.; Konopka, W.; Sandi, C.; Vasilaki, E. A generalised framework for detailed classification of swimming paths inside the Morris Water Maze. Sci. Rep. 2018, 8, 15089. [CrossRef]

34. Yuan, Z.; Zhou, H.; Zhou, N.; Dong, D.; Chu, Y.; Shen, J.; Han, Y.; Chu, X.P.; Zhu, K. Dynamic Evaluation Indices in Spatial Learning and Memory of Rat Vascular Dementia in the Morris Water Maze. Sci. Rep. 2019, 9, 7224. [CrossRef]

35. Zhao, L.; Peng, R.Y.; Wang, S.M.; Wang, L.F.; Gao, Y.B.; Dong, J.; Li, X.; Su, Z.T. Relationship between cognition function and hippocampus structure after long-term microwave exposure. Biomed. Environ. Sci. BES 2012, 25, 182-188. [CrossRef]

36. Deshmukh, P.S.; Megha, K.; Nasare, N.; Banerjee, B.D.; Ahmed, R.S.; Abegaonkar, M.P.; Tripathi, A.K.; Mediratta, P.K. Effect of Low Level Subchronic Microwave Radiation on Rat Brain. Biomed. Environ. Sci. BES 2016, 29, 858-867. [CrossRef]

37. Olivares-Bañuelos, T.N.; Chi-Castañeda, D.; Ortega, A. Glutamate transporters: Gene expression regulation and signaling properties. Neuropharmacology 2019, 161, 107550. [CrossRef]

38. Di, G.; Kim, H.; Xu, Y.; Kim, J.; Gu, X. A comparative study on influences of static electric field and power frequency electric field on cognition in mice. Environ. Toxicol. Pharmacol. 2019, 66, 91-95. [CrossRef] [PubMed]

39. He, S.; Zhang, X.; Qu, S. Glutamate, Glutamate Transporters, and Circadian Rhythm Sleep Disorders in Neurodegenerative Diseases. ACS Chem. Neurosci. 2019, 10, 175-181. [CrossRef]

40. Avoli, M. Inhibition, oscillations and focal seizures: An overview inspired by some historical notes. Neurobiol. Dis. 2019, 130, 104478. [CrossRef]

41. Pajarillo, E.; Rizor, A.; Lee, J.; Aschner, M.; Lee, E. The role of astrocytic glutamate transporters GLT-1 and GLAST in neurological disorders: Potential targets for neurotherapeutics. Neuropharmacology 2019, 161, 107559. [CrossRef]

42. Parkin, G.M.; Udawela, M.; Gibbons, A.; Dean, B. Glutamate transporters, EAAT1 and EAAT2, are potentially important in the pathophysiology and treatment of schizophrenia and affective disorders. World J. Psychiatry 2018, 8, 51-63. [CrossRef]

43. Wang, H.; Peng, R.; Zhao, L.; Wang, S.; Gao, Y.; Wang, L.; Zuo, H.; Dong, J.; Xu, X.; Zhou, H.; et al. The relationship between NMDA receptors and microwave-induced learning and memory impairment: A long-term observation on Wistar rats. Int. J. Radiat. Biol. 2015, 91, 262-269. [CrossRef]

44. Wang, L.-F.; Wei, L.; Qiao, S.-M.; Gao, X.-N.; Gao, Y.-B.; Wang, S.-M.; Zhao, L.; Dong, J.; Xu, X.-P.; Zhou, H.-M.; et al. MicrowaveInduced Structural and Functional Injury of Hippocampal and PC12 Cells Is Accompanied by Abnormal Changes in the NMDAR-PSD95-CaMKII Pathway. Pathobiology 2015, 82, 181-194. [CrossRef]

45. Wang, H.; Tan, S.; Dong, J.; Zhang, J.; Yao, B.; Xu, X.; Hao, Y.; Yu, C.; Zhou, H.; Zhao, L.; et al. iTRAQ quantitatively proteomic analysis of the hippocampus in a rat model of accumulative microwave-induced cognitive impairment. Environ. Sci. Pollut. Res. Int. 2019, 26, 17248-17260. [CrossRef]

46. Zuo, H.; Liu, X.; Wang, D.; Li, Y.; Xu, X.; Peng, R.; Song, T. RKIP-Mediated NF-кB Signaling is involved in ELF-MF-mediated improvement in AD rat. Int. J. Med. Sci. 2018, 15, 1658-1666. [CrossRef] [PubMed]

47. Hao, Y.; Li, W.; Wang, H.; Zhang, J.; Yu, C.; Tan, S.; Wang, H.; Xu, X.; Dong, J.; Yao, B.; et al. Autophagy mediates the degradation of synaptic vesicles: A potential mechanism of synaptic plasticity injury induced by microwave exposure in rats. Physiol. Behav. 2018, 188, 119-127. [CrossRef] [PubMed]

48. Kumar, M.; Singh, S.P.; Chaturvedi, C.M. Chronic Nonmodulated Microwave Radiations in Mice Produce Anxiety-like and Depression-like Behaviours and Calcium- and NO-related Biochemical Changes in the Brain. Exp. Neurobiol. 2016, 25, 318-327. [CrossRef]

49. Tan, S.; Wang, H.; Xu, X.; Zhao, L.; Zhang, J.; Dong, J.; Yao, B.; Wang, H.; Zhou, H.; Gao, Y.; et al. Study on dose-dependent, frequency-dependent, and accumulative effects of $1.5 \mathrm{GHz}$ and $2.856 \mathrm{GHz}$ microwave on cognitive functions in Wistar rats. Sci. Rep. 2017, 7, 10781. [CrossRef] [PubMed] 
50. Karimi, N.; Bayat, M.; Haghani, M.; Saadi, H.F.; Ghazipour, G.R. 2.45 GHz microwave radiation impairs learning, memory, and hippocampal synaptic plasticity in the rat. Toxicol. Ind. Health 2018, 34, 873-883. [CrossRef] [PubMed]

51. Jafari-Sabet, M.; Mofidi, H.; Attarian-Khosroshahi, M.-S. NMDA receptors in the dorsal hippocampal area are involved in tramadol state-dependent memory of passive avoidance learning in mice. Can. J. Physiol. Pharmacol. 2018, 96, 45-50. [CrossRef] [PubMed]

52. Ethell, I.M.; Pasquale, E.B. Molecular mechanisms of dendritic spine development and remodeling. Prog. Neurobiol. 2005, 75, 161-205. [CrossRef]

53. Ueda, S.; Negishi, M.; Katoh, H. Rac GEF Dock4 interacts with cortactin to regulate dendritic spine formation. Mol. Biol. Cell 2013, 24, 1602-1613. [CrossRef] [PubMed]

54. Nandini, H.S.; Paudel, Y.N.; Krishna, K.L. Envisioning the neuroprotective effect of Metformin in experimental epilepsy: A portrait of molecular crosstalk. Life Sci. 2019, 233, 116686. [CrossRef] 